\title{
Konsep Pembinaan Anak Dalam Lembaga Pembinaan Khusus Anak (LPKA) Dalam Perspektif Hak Asasi Manusia
}

\author{
Hartono \\ hartonoachien@gmail.com \\ Alumni Magister Ilmu Hukum Universitas Mulawarman
}

\begin{abstract}
ABSTRAK
Berdasarkan Undang-Undang Nomor 20 Tahun 2003 tentang Sistem Pendidikan Nasional maka anak yang ditempatkan dalam Lembaga Pembinaan Khusus Anak (LPKA) juga berhak mendapatkan pendidikan tanpa dibeda-bedakan dan pemerintah bertanggung jawab atas penyelenggaraan pendidikan tersebut. Ketika negara tidak mampu melaksanakan amanat undang-undang ini maka negara seharusnya menghindarkan anak-anak pelaku tindak pidana dari penerapan pidana penjara. Sistem peradilan pidana anak lebih ditekankan pada aspek pembinaan anak melalui pendidikan, rehabilitasi, reintegrasi dan tetap harus melalui pendekatan keadilan restoratif. Minimnya kerja sama dengan lembaga-lembaga sosial juga menjadi kendala tersendiri. Di Indonesia ada banyak institusi yang memiliki minat dengan anak, baik lembaga pemerintah seperti Kementerian Sosial, Kementerian Pemberdayaan Perempuan dan Perlindungan Anak, Komisi Perlindungan Anak Indonesia, Yayasan, Lembaga Swadaya Masyarakat dan lembaga sosial lainnya. Dengan banyaknya lembaga yang terkait seharusnya bisa dijadikan peluang dan tantangan bagaimana bisa mewujudkan kerjasama baik dalam bentuk MoU, kemitraan dan kerjasama lainnya untuk bersama-sama membangun anak yang sedang menjalani pidana penjara melalui pembinaan khususnya di bidang pendidikan. Untuk memujudkan hal tersebut di atas maka perlu dibangun kerjasama antar instansi misalnya untuk penyelenggaraan pendidikan formal dan informal menjadi tanggung jawab kementerian pendidikan, termasuk untuk mengeluarkan sertifikat bahwa anak telah memiliki kemampuan tertentu tanpa memberikan stigma negatif terhadap anak dan termasuk penyelenggaraan pelaksanaan dan standar pendidikan di Lembaga Pembinaan Khusus Anak. Setiap anak berhak untuk memperoleh pendidikan dan pengajaran dalam rangka pengembangan pribadinya sesuai dengan minat, bakat dan tingkat kecerdasannya, tanpa adanya diskriminasi yang merupakan hak untuk tumbuh kembang seperti yang termuat di dalam konvensi hak anak bagian daripada pemenuhan hak asasi manusia.
\end{abstract}

Kata Kunci: Hak, Asasi, Anak, Lembaga 


\begin{abstract}
Based on Law Number 20 Year 2003 regarding National Education System, the children placed in the Child Development Institution are also entitled to receive education without discrimination and the government is responsible for the implementation of the education. When a country is unable to carry out the mandate of this law, the state should avoid the children of the offender from imprisonment. Child criminal justice system is more emphasized on child development aspect through education, rehabilitation, re-integration and still have to go through restorative justice approach. The lack of cooperation with social institutions is also an obstacle. In Indonesia there are many institutions that have interests with children, including government agencies such as the Ministry of Social Affairs, the Ministry of Women Empowerment and Child Protection, the Indonesian Child Protection Commission, the Foundation, Non-Governmental Organization and other social institutions. With so many related institutions should be an opportunity and challenge how to realize cooperation in the form of $M o U$, partnership and other cooperation to jointly build a child who is undergoing imprisonment through coaching, especially in the field of education. In order to realize the above, it is necessary to establish cooperation among institutions such as for the implementation of formal and informal education into the responsibility of the ministry of education, including to issue a certificate that the child has a certain ability without giving negative stigma to the child and including the implementation of implementation and education standards at the Institute Special Child Coaching. Every child shall have the right to receive education and instruction in the framework of his personal development in accordance with his interests, talents and intelligence level, without any discrimination which is the right to grow and develop as contained in the Convention on the Rights of the Child rather than the fulfillment of human rights.
\end{abstract}

Keywords: Rights, Association, Children, Institution

\title{
PENDAHULUAN
}

\section{A. Latar Belakang}

Negara Republik Indonesia adalah Negara Hukum berdasarkan Pancasila dan Undang-Undang Dasar Negara Republik Indonesia Tahun 1945. Pada Pasal 1 ayat (3) Undang-Undang Dasar Negara Republik Indonesia Tahun 1945 menyebutkan bahwa Negara Indonesia adalah negara hukum. Salah satu ciri negara hukum adalah mengakui dan menjunjung tinggi Hak Asasi Manusia. Hak Asasi Manusia bukan hanya diperoleh oleh orang dewasa namun anak-anak juga berhak untuk memperolehnya.
Anak merupakan salah satu aset pembangunan nasional, patut dipertimbangkan dan diperhitungkan dari segi kualitas dan masa depannya. Tanpa kualitas yang handal dan masa depan yang jelas bagi anak, pembangunan nasional akan sulit dilaksanakan dan nasib bangsa akan sulit dibayangkan. ${ }^{1}$ Anak merupakan generasi penerus bangsa, sehingga negara memiliki kewajiban untuk memberikan perhatian dan perlindungan terhadap hakhak anak, tak terkecuali anak yang

\footnotetext{
${ }^{1}$ Bunadi Hidayat, 2010, Pemidanaan Anak di Bawah Umur, Alumni, Bandung, hal.01
} 
berkonflik dengan hukum. Tindak pidana yang dilakukan oleh seorang anak tidak menghalanginya untuk memperoleh hakhaknya, terutama hak atas pendidikan sebagaimana tercantum dalam Pasal 31 ayat (1) Undang-Undang Dasar Negara Republik Indonesia Tahun 1945 yang berupaya memberikan jaminan bagi setiap warga negaranya untuk memperoleh haknya atas pendidikan. Kemudian pada ayat (2) menyebutkan bahwa setiap warga negara wajib mengikuti pendidikan dasar dan pemerintah wajib membiayainya.

Hal ini sejalan dengan Deklarasi Universal Hak Asasi Manusia (DUHAM) yang ditanda tangani oleh negara-negara Perserikatan Bangsa-Bangsa (PBB) pada tanggal 10 Desember 1948, Pasal 26 ayat (1) yang menyebutkan setiap anak berhak memperoleh pendidikan. Pendidikan harus dengan cuma-cuma, setidaknya untuk tingkatan sekolah rendah dan pendidikan dasar. Kemudian pada Pasal 26 ayat (2) menyebutkan pendidikan harus ditujukan ke arah perkembangan pribadi yang seluasluasnya serta untuk mempertebal penghargaan terhadap hak asasi manusia dan kebebasan-kebebasan dasar. Kemudian didalam Undang-Undang Nomor 39 Tahun 1999 tentang Hak Asasi Manusia pada Pasal 60 ayat (1) menyebutkan bahwa setiap anak berhak untuk memperoleh pendidikan dan pengajaran dalam rangka pengembangan pribadinya sesuai dengan minat, bakat dan tingkat kecerdasannya.

Kondisi anak yang sedang mengalami masa pidananya di lembaga pemasyarakatan anak tidak membuat mereka kehilangan haknya untuk mendapat pendidikan sebagaimana diatur dalam Pasal 5 Undang-Undang Nomor 20 Tahun 2003 tentang Sistem Pendidikan Nasional yang menyebutkan bahwa:

1) Setiap warga negara mempunyai hak yang sama untuk memperoleh pendidikan yang bermutu;
2) Warga negara yang memiliki kelainan fisik, emosional, mental, intelektual, dan/atau sosial berhak memperoleh pendidikan khusus.

Selanjutnya Pasal 6 Undang-Undang Nomor 20 Tahun 2003 tentang Sistem Pendidikan Nasional mengatur tentang:

1) Setiap warga negara yang berusia 7 (tujuh) sampai dengan 15 (lima belas) tahun wajib mengikuti pendidikan dasar;

2) Setiap warga negara bertanggung jawab terhadap keberlangsungan penyelenggaraan pendidikan.

Berdasarkan Undang-Undang Nomor 20 Tahun 2003 tentang Sistem Pendidikan Nasional maka anak yang ditempatkan dalam Lembaga Pembinaan Khusus Anak (LPKA) juga berhak mendapatkan pendidikan tanpa dibeda-bedakan dan pemerintah bertanggung jawab atas penyelenggaraan pendidikan tersebut. Ketika negara tidak mampu melaksanakan amanat undang-undang ini maka negara seharusnya menghindarkan anak-anak pelaku tindak pidana dari penerapan pidana penjara.

Telah dijelaskan pada Pasal 81 ayat (5) Undang-Undang Nomor 11 Tahun 2012 tentang Sistem Peradilan Pidana Anak bahwa pidana penjara terhadap anak hanya digunakan sebagai upaya terakhir. Sehingga apabila anak dijatuhi pidana penjara ditempatkan di Lembaga Pembinaan Khusus Anak (LPKA) maka berhak memperoleh pembinaan, pembimbingan, pengawasan, pendampingan, pendidik- an dan pelatihan, serta hak lain sesuai dengan ketentuan peraturan perundang-undangan.

Terkait ketentuan mengenai pembinaan anak yang berkonflik dengan hukum masih mengacu pada Pasal 2 ayat (2) Peraturan Pemerintah Nomor 31 Tahun 1999 tentang Pembinaan dan Pembimbingan Warga Binaan 
Pemasyarakatan menjelaskan bahwa program pembinaan diperuntukkan bagi narapidana dan anak didik pemasyarakatan.

Baik Peraturan Pemerintah Nomor 31

Tahun 1999 tentang Pembinaan dan Pembimbingan Warga Binaan Pemasyarakatan maupun Undang-Undang Nomor 11 Tahun 2012 tentang Sistem Peradilan Pidana Anak belum mengatur secara khusus terkait mekanisme pembinaan terhadap anak khususnya pemenuhan hak tumbuh kembang anak berupa segala bentuk pendidikan baik formal maupun nonformal agar tercapai standar hidup yang layak bagi anak.

Pada pelaksanaan pembinaan anak di Lembaga Pembinaan Khusus Anak (LPKA) banyak mengalami hambatan, seperti yang dapat kita lihat pada tesis Mukhamad Tri Setyobudi dalam penelitiannya pada lembaga pemasyarakatan anak di kota Tangerang, Provinsi Banten menemukan 4 (empat) hal yang menghambat dalam pelaksanaan pembinaan anak pidana di lembaga pemasyarakatan anak wanita Tangerang, yaitu: ${ }^{2}$

1) Sumber Daya Manusia (SDM), dalam rangka pelaksanaan pembinaan anak pidana tersebut diperlukan pegawaipegawai yang memiliki keahlian khusus dalam menangani kebutuhan anak, namun dalam pelaksanaan masih terdapat kekurangan atau ketidakadaan pegawai dengan keahlian khusus, misalnya pegawai yang memiliki keahlian psikolog. Psikolog sangat diperlukan untuk membantu perkembangan kejiwaan terhadap anak pidana di dalam lapas dan sebagainya.

2) Sarana dan prasarana, hal ini sangat dibutuhkan dalam mempermudah

${ }^{2}$ Mukhamad Tri Setyobudi, 2012, Pembinaan Anak Pidana Di Lembaga Pemasyarakatan Anak Tanggerang, Tesis, Program Magister Ilmu Hukum Universitas Indonesia, Jakarta, hal.116 proses pembinaan terhadap anak pidana dan anak didik pemasyarakatan lainnya di dalam lapas, namun dalam pelaksanaan masih terdapat hambatan khususnya ketidaktersediaan pendidikan formal bagi anak pidana di dalam lapas. Hal ini disebabkan karena:

a) Kurikulum yang tersedia belum memenuhi standar yang ditentukan Pendidikan Nasional (DIKNAS);

b) Jumlah guru yang tersedia masih kurang; dan

c) Sarana prasarana untuk mendukung kegiatan belajar mengajar tingkat SLTA belum tersedia secara lengkap, seperti perpustakaan, kegiatan extrakurikuler, laboratorium dan lain-lain.

3) Keadaan penghuni lapas yang tidak dihuni oleh anak pidana saja tetapi juga bergabung dengan narapidana wanita dewasa, sehingga tidak menutup kemungkinan akan memberikan pengaruh yang buruk terhadap penghuni anak di dalam lapas.

4) Kultur, untuk mewujudkan tujuan pembinaan terhadap anak pidana perlu peran serta dari pihak lain untuk mewujudkannya. Salah satunya adalah keikutsertaan masyarakat dalam proses pembinaan diharapkan dapat membantu anak pidana untuk kembali seperti sedia kala, namun sebagian dari masyarakat masih memberikan stigma buruk terhadap narapidana dalam hal ini anak pidana dalam lapas, sehingga pembinaan yang dilakukan terhadap anak selama di dalam lapas menjadi sia-sia dan bukan tidak mungkin mereka akan mengulangi perbuatannya yaitu melakukan pelanggaran terhadap hukum. 
Hal yang sama disampaikan pula oleh Alden Juniedy Simanjuntak dalam jurnalnya mengenai perlindungan hukum terhadap anak yang menjalani pemidanaan di lembaga pemasyarakatan anak Kelas II B Pontianak dalam kesimpulannya menjelaskan terkait pembinaan anak pidana mengalami kendala terkait kurangnya tenaga ahli yang berkompeten dalam menangani masalah anak, sehingga anakanak yang menjalani pidana tidak bisa dibina dan dididik secara serius. Dan yang lebih penting lagi belum tersedianya peraturan khusus yang mengatur tentang perlindungan terhadap anak yang menjalani pidana di lembaga pemasyarakatan, terutama bagi mereka yang tidak ditempatkan di lembaga pemasyarakatan anak. ${ }^{3}$ Demikian pula disampaikan oleh Asri Rima Jiwantari dalam jurnalnya mengenai manajemen pembinaan anak didik pemasyarakatan studi kasus LPKA Kelas II Jakarta dalam hasil penelitiannya menyimpulkan bahwa dalam kegiatan pembinaaan bagi anak didik pemasyarakatan masih bekerja sama dengan pihak yayasan dan LSM, belum tersedianya anggaran menyebabkan pelaksanaan program pembinaan belum dapat dilakukan secara maksimal sesuai rencana kerja. ${ }^{4}$ Anak yang berkonflik dengan hukum memiliki hak-hak yang sama dengan anak pada umumnya diluar Lembaga Pembinaan Khusus Anak (LPKA). Mereka juga merupakan generasi penerus bangsa yang harus dilindungi dari perilaku nondiskriminasi. Termasuk dalam hal pemenuhan hak anak atas pendidikan

3 Alden Juniedy Simanjuntak, 2013, Perlindungan Hukum Terhadap Anak Yang Menjalani Pidana Penjara Di Lembaga Pemasyarakatan Anak Kelas IIB Pontianak, Jurnal Nestor Magister Hukum, Vol.2, No.2 Tahun 2013.

4 Asri Rima Jiwantari, 2017, Manajemen Pembinaan Anak Didik Pemasyarakatan Studi Kasus LPKA Kelas II Jakarta, Jurnal Ilmiah untuk peningkatan mutu manajemen pendidikan, Vol.4, No.1 tahun 2017. sebagaimana merupakan tanggungjawab daripada negara dan masyarakat selama berada di Lembaga Pembinaan Khusus Anak (LPKA). Hal ini sangatlah penting untuk dilaksanakan mengingat untuk kepentingan kelangsungan hidup anak yang diharapkan pada saat keluar dari penjara, mereka dapat diterima kembali oleh masyarakat sehingga mencegah anak untuk yang melindungi hak asasi anak yang mengulangi kembali perbuatan pidana.

Maka perlu adanya konsep pembinaan berkonflik dengan hukum ditempatkan pada Lembaga Pembinaan Khusus Anak (LPKA) dalam sebuah regulasi atau aturan khusus yang mengatur pemenuhan hak atas pendidikan dan pelatihan ketrampilan termasuk sarana prasarana dalam rangka pengembangan pribadinya sesuai dengan minat, bakat, dan tingkat kecerdasannya. Sehingga terwujud prinsip dasar dari hak asasi anak antara lain non diskriminasi dan kepentingan yang terbaik bagi anak.

\section{B. Rumusan Masalah}

Berdasarkan uraian yang telah disampaikan maka adapun rumusan masalah yang ingin disampaikan adalah sebagai berikut:

1) Bagaimana konsep pembinaan anak yang berkonflik dengan hukum dalam Lembaga Pembinaan Khusus Anak (LPKA) ditinjau dari perspektif Hak Asasi Manusia?

2) Bagaimana mewujudkan pemenuhan hak anak atas pendidikan selama di dalam Lembaga Pembinaan Khusus Anak (LPKA) ? 


\section{Tujuan Penelitian}

Berdasarkan latar belakang dan perumusan masalah sebagaimana diuraikan diatas, tujuan penelitian diarahkan untuk menjawab 2 (dua) hal yakni:

1) Untuk mengetahui dan menganalisis konsep pembinaan anak yang berkonflik dengan hukum dalam Lembaga Pembinaan Khusus Anak (LPKA) ditinjau dari perspektif Hak Asasi Manusia; dan

2) Untuk mengetahui dan menganalisis cara mewujudkan pemenuhan hak anak atas pendidikan selama di dalam Lembaga Pembinaan Khusus Anak (LPKA).

\section{Manfaat Penelitian}

Penelitian yang berjudul "Konsep Pembinaan anak Yang Berkonflik Dengan Hukum Dalam Lembaga Pembinaan Khusus Anak (LPKA) Ditinjau Dari Perspektif Hak Asasi Manusia" diharapkan bermanfaat baik secara tertulis maupun secara praktis, yaitu sebagai berikut:

1) Secara teoritis, penelitian ini diharapkan dapat menambah bahanbahan ilmiah dalam melihat kasuskasus mengenai pembinaan anak yang berkonflik dengan hukum khususnya dalam sistem peradilan pidana anak di Indonesia;

2) Secara praktis, dari hasil penelitian kelak diharapkan dapat memberikan sumbangan pikiran dalam pembentukan regulasi dan konsep yang ideal bagi anak yang berada di Lembaga Pembinaan Khusus Anak (LPKA).

\section{TINJAUAN PUSTAKA}

\section{Hak Asasi Manusia}

Hak Asasi Manusia adalah hak-hak yang diberikan langsung oleh Tuhan Yang
Maha Pencipta (hak-hak yang bersifat kodrati). Oleh karena itu, tidak ada kekuasaan apapun di dunia yang dapat mencabutnya. Meskipun demikian bukan berarti manusia dengan hak-haknya itu dapat berbuat semau-maunya. Sebab apabila seseorang melakukan sesuatu yang dapat dikategorikan melanggar hak asasi orang lain, maka ia harus mempertanggungjawabkan perbuatannya. Pada hakikatnya Hak Asasi Manusia terdiri atas 2 (dua) hak dasar yang paling fundamental, yaitu hak persamaan dan hak kebebasan. Dari kedua hak dasar inilah lahir Hak Asasi Manusia yang lainnya atau tanpa kedua hak dasar ini Hak Asasi Manusia lainnya sulit akan ditegakkan. ${ }^{5}$

Hak Asasi Manusia (selanjutnya disingkat HAM) merupakan hak-hak yang melekat pada manusia yang mencerminkan martabatnya, yang harus memperoleh jaminan hukum, sebab hak-hak hanya dapat efektif apabila hak-hak itu dapat dilindungi hukum. Melindungi hak-hak dapat terjamin, apabila hak-hak itu merupakan bagian dari hukum, yang memuat prosedur hukum untuk melindungi hak-hak tersebut. hukum pada dasarnya merupakan pencerminan dari HAM, sehingga hukum itu mengandung keadilan atau tidak, ditentukan oleh HAM yang dikandung dan diatur atau dijamin oleh hukum itu. Hukum tidak lagi dilihat sebagai refleksi kekuasaan semata-mata, tetapi juga harus memancarkan perlindungan terhadap hak-hak warga negara. ${ }^{6}$

HAM mempunyai ruang lingkup yang luas dan mencakup berbagai aspek

${ }^{5}$ Baharuddin Lopa, 1996, Alquran dan HakHak Asasi Manusia, Dana Bhakti Prima Yasa, Yogyakarta, hal.2

6 Muladi, 1995, Kapita Selekta Sistem Peradilan Pidana, Badan Penerbit Universitas Diponegoro, Semarang, hal.45 
kehidupan. Hal ini diungkapkan sebagai berikut: $^{7}$

1) Setiap orang berhak atas perlindungan diri pribadi, keluarga, kehormatan, martabat dan hak miliknya;

2) Setiap orang berhak atas pengakuan di depan hukum sebagai manusia pribadi di mana saja ia berada;

3) Setiap orang berhak atas rasa aman dan tentram serta perlindungan terhadap ancaman ketakutan untuk berbuat atau tidak berbuat sesuatu;

4) Setiap orang tidak boleh diganggu yang merupakan hak yang berkaitan dengan kehidupan pribadi di dalam tempat kediamannya;

5) Setiap orang berhak atas kemerdekaan dan rahasia dalam hubungan komunikasi melalui sarana elektronik, tidak boleh diganggu, kecuali atas perintah hakim atau kekuasan lain yang sah sesuai dengan undangundang;

6) Setiap orang berhak untuk bebas dari penyiksaan, penghukuman, atau perlakuan yang kejam, tidak manusiawi, penghilangan paksa, dan penghilangan nyawa;

7) Setiap orang tidak boleh ditangkap, ditekan, disiksa, dikucilkan, diasingkan, atau dibuang secara sewenang-wenang; dan

8) Setiap orang berhak hidup dalam tatanan masyarakat dan kenegaraan yang damai, aman dan tenteram, yang menghormati, melindungi dan melaksanakan sepenuhnya hak asasi manusia dan kewajiban dasar manusia sebagaimana diatur dalam undangundang.

Di Indonesia, hak asasi manusia tidak dapat dipisahkan dengan pandangan

${ }^{7}$ Zainuddin Ali, 2006, Filsafat Hukum, Sinar Grafika, Jakarta, hal.147 filosofis bangsa Indonesia yang terkandung dalam Pancasila, bahwa hakekat manusia adalah monopluralis. Susunan kodrat manusia adalah jasmani dan rohani yang sifat dan kodratnya manusia adalah makhluk individu dan makhluk sosial serta berkedudukan kodrat sebagai makhluk pribadi yang berdiri sendiri dan sebagai makhluk Tuhan Yang Maha Esa. Berdasarkan tujuan negara yang diatur dalam Undang-Undang Dasar Negara Republik Indonesia Tahun 1945 menyebutkan bahwa negara Indonesia menjamin dan melindungi hak-hak asasi manusia para warganya, terutama berkaitan dengan kesejahteraan hidupnya baik jasmaniah maupun rohaniah, antara lain berkaitan dengan hak-hak asasi bidang sosial, politik, ekonomi dan kebudayaan, pendidikan dan agama, yang rinciannya dimuat dalam Bab XA tentang Hak Asasi Manusia. ${ }^{8}$

Dengan diundangkannya UndangUndang Nomor 39 Tahun 199 tentang HakHak Asasi Manusia, maka jaminan hak asasi manusia yang terkandung dalam Undang-Undang Dasar Negara Republik Indonesia Tahun 1945 semakin efektif. Pada Pasal 1 angka (1) menyebutkan bahwa Hak Asasi Manusia adalah seperangkat hak yang melekat pada hakikat dan keberadaan manusia sebagai makhluk Tuhan Yang Maha Esa dan merupakan anugerah-Nya yang wajib dihormati, dijunjung tinggi dan dilindungi oleh negara, hukum dan pemerintah dan setiap orang demi kehormatan serta perlindungan harkat dan martabat manusia. ${ }^{9}$

8 Abintoro Prakoso, 2016, Pembaharuan Sistem Peradilan Pidana Anak Edisi Revisi, Aswaja Pressindo, Yogyakarta, hal.10

9 Abintoro Prakoso, 2010, Diskresi Pada Tahap Penyidikan Dalam Rangka Mewujudkan Perlindungan Hukum Bagi Anak Nakal, Disertasi pada Program Pascasarjana Fakultas Hukum Universitas Brawijaya, Malang, hal.88 
Keberadaan HAM di Indonesia berlaku mutlak bagi setiap warga negaradan harus dilindungi, namun demikian di samping HAM terdapat pula kewajiban dasar manusia, yang dimaksud kewajiban dasar manusia adalah seperangkat kewajiban yang apabila tidak dilaksanakan, tidak memungkinkan terlaksananya dan tegaknya HAM, sehingga ada timbal balik antara hak dan kewajiban yang saling memengaruhi, di mana apabila kewajibannya tidak dilaksanakan dapat dipastikan tidak akan tercapai pelaksanaan HAM. Sehingga kewajiban dasar itu sangat mempengaruhi tegaknya Hak Asasi Manusia.

\section{Konvensi Hak Anak}

Konvensi Hak Anak Tahun 1989 yang disepakati dalam sidang Majelis Umum (General Assembly) PBB ke-44, yang selanjutnya dituangkan dalam Resolusi PBB Nomor 44/25 tanggal 5 Desember 1989, Konvensi Hak Anak ini merupakan hukum internasional yang mengikat negara peserta (state parties), termasuk Indonesia. Berdasarkan materi hukum yang tercakup di dalam Konvensi Hak Anak dapat dikualifikasikan beberapa isi konvesi, yaitu: ${ }^{10}$

1) Penegasan hak-hak anak;

2) Perlindungan anak oleh negara; dan

3) Peran serta berbagai pihak (pemerintah, masyarakat dan swasta) dalam menjamin penghormatan terhadap hak-hak anak.

Konvensi Hak Anak terdiri atas 54 (lima puluh empat) pasal yang berdasarkan materi hukumnya mengatur mengenai hakhak anak dan mekanisme implementasi hak anak oleh negara peserta yang meratifikasi Konvensi Hak Anak. Materi hukum mengenai hak-hak anak dalam konvensi hak anak tersebut, dapat dikelompokkan dalam 4 (empat) kategori hak-hak anak, yaitu: ${ }^{11}$

1) Hak terhadap kelangsungan hidup (Survival Rights), Yaitu hak-hak anak dalam Konvensi Hak Anak yang meliputi hak-hak untuk melestarikan dan mempertahankan hidup (the rights of life) dan hak untuk memperoleh standar kesehatan tertinggi dan perawatan yang sebaik-baiknya (the rights to the highest standar of health and medical care attainable). Terkait dengan itu hak anak akan kelangsungan hidup meliputi pula:

a) Hak anak untuk mendapatkan nama dan kewarganegaraan semenjak dilahirkan;

b) Hak untuk memperoleh perlindungan dan memulihkan kembali aspek dasar jati diri anak (nama, kewarganegaraan, dan ikatan keluarga);

c) Hak anak untuk hidup bersama;

d) Hak anak untuk memperoleh perlindungan dari segala bentuk salah perlakuan yang dilakukan oleh orang tua atau orang lain yang bertanggung jawab atas pengasuhan;

e) Hak untuk memperoleh perlindungan khusus bagi anak yang kehilangan lingkungan keluarganya dan menjamin pengusahaan keluarga atau penempatan institusional yang sesuai dengan mempertimbangkan latar budaya anak;

f) Adopsi anak hanya dibolehkan dan dilakukan demi kepentingan terbaik anak, dengan segala perlindungan yang disahkan oleh pejabat yang berwenang;

\footnotetext{
${ }^{11}$ Ibid, hal.35 Op. Cit, hal.33 
g) Hak-hak anak penyandang cacat (disabled) untuk memperoleh pengasuhan, pendidikan, dan pelatihan khusus yang dirancang untuk membantu mereka demi mencapai tingkat kepercayaan diri yang tinggi; dan

h) Hak anak menikmati standar kehidupan yang memadai dan hak atas pendidikan.

2) Hak terhadap Perlindungan (Protection Rights), Yaitu hak-hak anak dalam Konvensi Hak Anak yang meliputi hak perlindungan dari diskriminasi, tindak kekerasan dan keterlantaran bagi anak yang tidak mempunyai keluarga bagi anak-anak pengungsi. Hak perlindungan dari diskriminasi, termasuk perlindungan anak penyandang cacat untuk memperoleh pendidikan, perawatan, dan pelatihan khusus, serta hak anak dari kelompok masyarakat minoritas dan penduduk asli dalam kehidupan masyarakat negara. Perlindungan dari eksploitasi meliputi:

a) Perlindungan dari gangguan kehidupan pribadi;

b) Perlindungan dari keterlibatan dalam pekerjaan yang mengancam kesehatan, pendidikan, dan perkembangan anak;

c) Perlindungan dari penyalahgunaan obat bius dan narkotika;

d) Perlindungan dari upaya penganiayaan seksual, prostitusi dan pornografi;

e) Perlindungan dari upaya penjualan, penyeludupan dan penculikan anak; dan

f) Perlindungan dari proses hukum bagi anak yang didakwa atau diputus telah melakukan pelanggaran hukum.

3) Hak untuk Tumbuh Kembang (Development Rights), Yaitu hak-hak anak dalam Konvensi Hak Anak yang meliputi segala bentuk pendidikan (formal dan nonformal) dan hak untuk mencapai standar hidup yang layak bagi perkembangan fisik, mental, spiritual, moral dan sosial anak. Hak anak atas pendidikan diatur dalam Pasal 28 Konvensi Hak-Hak Anak yang menyebutkan bahwa:

a) Negara menjamin kewajiban pendidikan dasar dan menyediakan secara cumacuma;

b) Mendorong pengembangan macam-macam bentuk pendidikan dan mudah dijangkau oleh setiap anak;

c) Membuat informasi dan bimbingan pendidikan dan keterampilan bagi anak;

d) Mengambil langkah-langkah untuk mendorong kehadirannya secara teratur di sekolah dan pengurangan angka putus sekolah;

e) Hak untuk memperoleh informasi;

f) Hak untuk bermain dan rekreasi;

g) Hak untuk berpartisipasi dalam kegiatan budaya;

h) Hak untuk kebebasan berpikir dan beragama;

i) Hak untuk mengembangkan kepribadian;

j) Hak untuk memperoleh identitas;

k) Hak untuk didengar pendapatnya; dan

1) Hak untuk memperoleh pengembangan kesehatan dan fisik. 
4) Hak untuk Berpartisipasi (Participation Rights), Yaitu hakhak anak dalam Konvensi Hak Anak yang meliputi hak anak untuk menyatakan pendapat dalam segala hal yang mempengaruhi anak (the rights of a child to express her/his views in all metters affecting that child). Hak yang terkait dengan ini, meliputi:

a) Hak untuk berpendapat dan memperoleh pertimbangan atas pendapatnya;

b) Hak untuk mendapat dan mengetahui informasi serta untuk mengekpresikan;

c) Hak untuk berserikat menjalin hubungan untuk bergabung; dan

d) Hak untuk memperoleh informasi yang layak dan terlindung dari informassi yang tidak sehat.

\section{Teori Pemidanaan Relatif (Pemidanaan dilihat dari tujuannya)}

Teori relatif (tujuan) bertitik pangkal pada dasar pidana adalah alat untuk menegakkan tata tertib (hukum) dalam masyarakat. Teori ini berbeda dengan teori absolut, dasar pemikiran suatu kejahatan dapat dijatuhi hukuman artinya penjatuhan pidana mempunyai tujuan tertentu, misalnya memperbaiki sikap mental atau membuat pelakunya tidak berbahaya lagi, dibutuhkan proses pembinaan sikap mental.

Teori relatif juga disebut teori tujuan, karena menitikberatkan pada tujuan hukuman. Teori relatif memandang bahwa pemidanaan bukan sebagai pembalasan atas si pelaku, tetapi sebagai sarana mencapai tujuan yang bermanfaat untuk melindungi masyarakat menuju kesejahteraan masyarakat. Menurut Leonard Orland dalam Solehuddin mengatakan bahwa teori relatif bertujuan mencegah dan mengurangi kejahatan. Pidana harus dimaksudkan untuk mengubah tingkah laku penjahat dan orang lain berpotensi atau cenderung melakukan kejahatan. ${ }^{12}$ Menurut Muladi tentang teori relatif mengatakan pemidanaan bukan sebagai pembalasan atas kesalahan pelaku tetapi sarana mencapai tujuan yang bermanfaat untuk melindungi masyarakat menuju kesejahteraan masyarakat. Sanksi ditekankan pada tujuannya, yakni untuk mencegah agar orang tidak melakukan kejahatan, maka bukan bertujuan untuk pemuasan absolut atas keadilan. ${ }^{13}$ Menurut Karl O. Christianse mengatakan bahwa ada beberapa ciri pokok dari teori relatif, yaitu: ${ }^{14}$

1) Tujuan pidana adalah pencegahan;

2) Pencegahan bukan tujuan akhir tetapi hanya sebagai sarana untuk mencapai tujuan yang lebih tinggi yaitu kesejahteraan masyarakat;

3) Hanya pelanggaran hukum yang dapat dipersalahkan kepada si pelaku saja, misalnya kesengajaan atau kelalaian yang memenuhi syarat untuk adanya pidana;

4) Pidana harus ditetapkan berdasarkan tujuannya sebagai alat pencegahan kejahatan; dan

5) Pidana melihat ke depan atau bersifat prospektif, ia mengandung unsur pencelaan tetapi baik unsur pencelaan maupun unsur pembalasan tidak dapat diterima bisa tak dapat membantu pencegahan kejahatan untuk kepentingan masyarakat.

Teori ini memunculkan tujuan pemidanaan sebagai sarana pencegahan, baik pencegahan khusus (speciale preventie) yang ditujukan kepada pelaku

\footnotetext{
${ }^{12}$ Ibid, hal.92

13 Zainal Abidin Farid, 2007, Hukum Pidana I, Sinar Grafika, Jakarta, hal.11

${ }^{14}$ La Sina, 2016, Hukum Dan Hak Asasi Manusia, Kreasi Total Media, Yogyakarta, hal.92
} 
maupun pencegahan umum (general preventie) yang ditujukan ke masyarakat. Teori relatif ini berasas pada 3 (tiga) tujuan utama pemidanaan yaitu preventif, detterence, dan reformatif. Tujuan preventif (prevention) untuk melindungi masyarakat dengan menempatkan pelaku kejahatan terpisah dari masyarakat. Tujuan menakuti (detterence) untuk menimbulkan rasa takut melakukan kejahatan, baik bagi individual pelaku agar tidak mengulangi perbuatannya, maupun bagi publik sebagai langkah panjang. Sedangkan tujuan perubahan (reformation) untuk mengubah sifat jahat si pelaku dengan dilakukannya pembinaan dan pengawasan, sehingga nantinya dapat kembali melanjutkan kebiasaan hidupnya sehari-hari sebagai manusia yang sesuai dengan nilai-nilai yang ada di masyarakat.

\section{Teori Pembinaan (Rehabilitation Theory)}

Pembinaan / rehabilitation sebagai pemidanaan dikemukakan oleh aliran positif yang berpendapat bahwa pemidanaan sangat pantas diarahkan kepada pelaku kejahatan, bukan pada perbuatannya. Namun pemidanaan yang dimaksudkan oleh teori pembinaan ini untuk memberi tindakan perawatan (treatment) dan perbaikan (rehabilitation) kepada pelaku kejahatan sebagai pengganti dari penghukuman. Argumen aliran teori pembinaan ini dilandaskan pada alasan bahwa pelaku kejahatan adalah orang yang sakit sehingga membutuhkan tindakan perawatan (treatment) dan perbaikan (rehabilitation). ${ }^{15}$ Menurut Herbert L.Packer, tujuan pemidanaan adalah untuk mengubah tingkah laku/kepribadian narapidana agar ia meninggalkan kebiasaan buruk yang bertentangan dengan norma-

15 C.Ray Jeffery, 1977, Crime Prevention Through Environmental Design, Sage Publication, Bevery Hills London, hal.18 norma hukum serta norma-norma lainnya dan agar ia lebih cenderung untuk mematuhi norma-norma yang berlaku. Teori pembinaan lebih diarahkan pada perbaikan narapidana, bukan pada tindak pidana yang telah terjadi. Sehingga pelaku tindak pidana tidak mengulangi lagi perbuatannya dan dapat diterima di masyarakat. ${ }^{16}$ Menurut Gerber dan Mc Anany menyatakan bahwa munculnya teori pembinaan dalam ilmu pemidanaan sejalan dengan gerakan reformasi penjara. Melalui pendekatan kemanusiaan, maka paham ini melihat bahwa sistem pemidanaan pada masa lampau menyebabkan tidak adanya kepastian nasib seseorang. Berdasarkan pendekatan keilmuan, maka aliran pembinaan atau rehabilitasi berusaha membuat jelas dan melahirkan suatu dorongan untuk memperbaiki pelaku kejahatan sebagai tema sentral mengenyampingkan semua tujuan lain dari pemidanaan. ${ }^{17}$ Menurut Jackson Toby bahwa perbaikan terhadap pelaku kejahatan merupakan gelombang besar dari gerakan konformis yang dipengaruhi oleh tuntutan humanisme dan menggunakan pendekatan keilmuan dalam ilmu pemidanaan yang lebih konstruktif dari pada penghukuman. Sebagian besar dari argumen paham pembinaan ini adalah penentangan terhadap pemenjaraan dan bentuk-bentuk lain dari pemidanaan dalam kepustakaan penjara singkat yang dinyatakan secara tegas bahwa pemidanaan (punishment) bertentangan dengan perbaikan (rehabilitation). ${ }^{18}$

${ }^{16}$ Herbert L.Packer, 1988, The limit of the criminal sanction, Standford University Press, California, hal.53

17 Gerber, Patrick D.Mc Anany, 1970, Philosophy of Punishment, John Wiley \& Sons, New York, hal.352

18 Jackson Toby, 1970, The Sociology of punishment and correction, Wiley \& Sons, New York, hal.366 


\section{Model-Model Pembinaan Anak}

Gordon Bazemore memperkenalkan

3 (tiga) corak atau model peradilan anak, yaitu: ${ }^{19}$

1) Model Pembinaan Pelaku Perorangan (individual treatment model)

Model pembinaan pelaku perorangan dalam praktek menggunakan pendekatan terapeutik yakni anak diperlakukan sebagai orang yang sakit kemudian harus didiagnosis sakitnya terlebih dahulu. Atas dasar temuan penyebab penyakitnya maka ditentukan terapi yang sesuai untuk mengobatinya. Terapi ini bersifat perorangan. Corak atau model pembinaan pelaku perorangan ini dirasakan kelemahannya terutama tidak terjamin timbulnya stigmatisasi, paternalistic, mahal, tidak memadai dan jaminan hukumnya lemah serta diragukan intensitasnya. Model ini dilihat masih belum berhasil mengarahkan secara formal kebutuhan untuk meningkatkan efektivitas sanksi terhadap anak pelaku delinkuen dan gagal memainkan peran dari peradilan anak dalam kerangka kepentingan publik.

\section{2) Model Retributif (retributive model)}

Model retributif memiliki tujuan pemberian ganjaran atau punishment. Hal ini dimaksudkan sebagai upaya untuk merasionalisasikan ketidakpastian pembuatan keputusan dalam persidangan anak, dan untuk menegaskan kembali pentingnya fungsi sanksi. Konsekuensi yang muncul kemudian adalah tuntutan akan perlunya mengadopsi pedoman pemberian pidana yang pasti, undangundang tentang anak tidak lagi menekankan rehabilitasi dan membuang kerangka acuan berorientasi pada keperluan pelaku.

19 Paulus Hadisuprapto, 2006, Peradilan Restoratif: Model Peradilan Anak Indonesia Masa Datang, Universitas Diponegoro, Semarang, hal.6
3) Model Restoratif (restorative model)

Model peradilan anak restoratif berangkat dari asumsi bahwa tanggapan atau reaksi terhadap perilaku delinkuen si anak, tidak akan efektif tanpa adanya kerjasama dan keterlibatan dari korban, pelaku dan masyarakat. Prinsip yang menjadi dasar pada model peradilan restoratif ini bahwa keadilan paling baik terlayani, apabila setiap pihak menerima perhatian secara adil dan seimbang, aktif dilibatkan dalam proses peradilan dan memperoleh keuntungan secara memadai dari interaksi mereka dengan sistem peradilan anak. Model peradilan restoratif berkehendak untuk memperbaiki kesejahteraan masyarakat melalui cara-cara menghadapkan pelaku anak pada pertanggungjawaban atas perilakunya.

\section{Program-Program Pembinaan} Anak

Model pembinaan bagi narapidana dewasa dan anak dilaksanakan berdasarkan Peraturan Pemerintah Nomor 31 Tahun 1999 tentang Pembinaan dan Pembimbingan Warga Binaan Pemasyarakatan. Pembinaan yang berbasis pendidikan layak anak, sejalan dengan arti pendidikan sendiri yaitu pembinaan yang berusaha menciptakan anak didik pemasyarakatan yang memiliki kekuatan spiritual keagamaan, pengendalian diri, kepribadian, kecerdasan, akhlak mulia, serta keterampilan yang diperlukaan dirinya, yang akan berdampak baik bagi masyarakat, bangsa dan negara. Anak yang ditempatkan dalam Lembaga Pembinaan Khusus Anak (LPKA) berhak mendapatkan pendidikan berupa pendidikan formal, non- 
formal maupun informal yang dapat dijelaskan sebagai berikut:

1) Pendidikan Formal, Undang-Undang Nomor 20 Tahun 2003 tentang Sistem Pendidikan Nasional (Sisdiknas) menyebutkan pendidikan formal adalah jalur pendidikan yang terstruktur dan berjenjang yang terdiri atas pendidikan dasar, pendidikan menengah dan pendidikan tinggi.

2) Pendidikan Non-formal, Undang-Undang Nomor 20 Tahun 2003 tentang Sistem Pendidikan Nasional (Sisdiknas) menyebutkan pendidikan non-formal adalah jalur pendidikan di luar pendidikan formal yang dapat dilaksanakan terstruktur dan berjenjang. Pada Pasal 26 UndangUndang Sisdiknas menyebutkan pendidikan non-formal meliputi pendidikan kecakapan hidup, pendidikan anak usia dini, pendidikan kepemudaan, pendidikan pemberdayaan perempuan, pendidikan keaksaraan, pendidikan keterampilan dan pelatihan kerja, pendidikan kesetaraan, serta pendidikan lain yang ditujukan untuk mengembangkan kemampuan peserta didik. Contoh pendidikan non-formal yaitu pendidikan kesetaraan (Paket A, Paket B dan Paket C), pendidikan keterampilan dan lain-lain.

3) Pendidikan Informal,

Pendidikan yang dilakukan oleh keluarga dan lingkungan berbentuk kegiatan belajar secara mandiri. Hasil pendidikan diakui sama dengan pendidikan formal dan non-formal setelah peserta didik lulus ujian sesuai dengan standar nasional pendidikan.

\section{METODE PENELITIAN}

Metode penulisan hukum normatif ini menggunakan beberapa penelitian hukum, yaitu penelitian terhadap teori-teori hukum yang relevan dalam menjawab permasalahan yang diangkat, konseptual penelitian yang merujuk pada prinsipprinsip hukum yang dapat ditemukan dalam pandangan-pandangan para sarjana hukum ataupun doktrin-doktrin hukum dan juga peraturan perundang-undangan yang bersangkut paut dengan isu hukum yang diketengahkan.

\section{PEMBAHASAN}

A. Konsep Pembinaan Yang Ideal Bagi Anak Berkonflik Dengan Hukum di Dalam Lembaga Pembinaan Khusus Anak (LPKA)

Dalam pelaksanaan programprogram pembinaan di Lembaga Pembinaan Khusus Anak (LPKA) masih belum seragam di tiap-tiap daerah. hal ini karena masih disesuaikan dengan kondisi dan kemampuan LAPAS di daerah-daerah. peningkatan kemampuan dan kualitas aparat sangat penting dilakukan untuk mendukung kelancaran pelaksanaan program pembinaan terhadap anak selain sarana dan prasarana yang menunjang juga sangat diperlukan. Sehingga dalam mewujudkan proses pembinaan yang memadai bagi anak di Lembaga Pembinaan Khusus Anak tentu terkait erat dengan beban biaya yang perlu dikeluarkan oleh lembaga pemasyarakatan. Pelaksanaan pendidikan bagi anak yang berada di lembaga pemasyarakatan belum memiliki standar yang sesuai dengan kebutuhan pendidikan anak. Sementara pada Pasal 6 Undang-Undang Nomor 20 Tahun 2003 tentang Sistem Pendidikan Nasional (Sisdiknas) menegaskan bahwa setiap warga negara yang berusia 7 (tujuh) sampai 
dengan 15 (lima belas) tahun wajib mengikuti pendidikan dasar, dan setiap warga negara bertanggung jawab terhadap keberlangsungan penyelenggaraan pendidikan. Sehingga dapat disimpulkan bahwa anak yang berada di lembaga pemasyarakatan juga berhak mendapatkan pendidikan tanpa dibeda-bedakan dan pemerintah bertanggung jawab atas penyelenggaraan pendidikan tersebut. Anak berhak mendapatkan pendidikan berupa pendidikan formal, non-formal maupun informal. Dalam mencari solusi terhadap kendala-kendala dalam pelaksanaan pembinaan yang ideal di Lembaga Pembinaan Khusus Anak yang telah dijelaskan di atas, penulis mencoba melakukan perbandingan dengan negara seperti Thailand, Filipina dan Malaysia. Dimana negara-negara tersebut dapat dijadikan konsep pembinaan anak yang berada di Lembaga Pembinaan Khusus Anak (LPKA), sehingga diharapkan dapat terbentuknya regulasi atau aturan terkait standar penyelenggaraan pendidikan bagi anak yang berada di Lembaga Pembinaan Khusus Anak (LPKA).

Seperti di Thailand terdapat lembaga pemasyarakatan khusus untuk anak yang dinamakan Ban Kanchanapisek. Jika konotasi LAPAS untuk anak yang biasanya dipenuhi dengan stigma negatif sebagai penjara bagi para anak-anak nakal, maka berbeda dengan Thailand. Konsep dari Ban Kanchanapisek lebih kepada rumah yang tidak memiliki pagar, ruang tahanan maupun seragam penjara. Kondisi LAPAS lebih cocok disebut sebagai rumahnya anak yang bermasalah. di sini anak yang sedang menjalani masa hukumannya dilatih dan dididik dengan berbagai kegiatan-kegiatan positif dan pelatihan untuk bekal mereka di kemudian hari. Bahkan, terdapat kegiatan nonton bersama pada hari tertentu di setiap minggunya, pelatihan ketrampilan membuat makanan, melukis, keterampilan salon, dan tersedianya kelas-kelas bagi para anak-anak untuk belajar. Meskipun dana yang diluncurkan pemerintah ke lembaga ini sangat minim, tidak menjadi halangan bagi lembaga untuk menyelenggarakan program pembinaan ini. Jalan yang ditempuh dalam rangka melaksanakan program pembinaan anak adalah dengan mendirikan yayasan untuk membiayai kegiatan-kegiatan yang dilakukan oleh lembaga ini, yaitu dengan cara mengadakan kegiatan-kegiatan bazar guna pemasukan dana kegiatan operasional mereka. ${ }^{20} \mathrm{Hal}$ ini dapat dicontoh oleh Indonesia sehingga kendala klasik seperti minimnya anggaran seharusnya tidak menjadikan hal itu sebagai hambatan, tetapi peluang dan tantangan untuk mendapatkan ide-ide dan gagasan dengan memaksimalkan anggaran yang ada dan juga melakukan berbagai inovasi untuk menghasilkan dana pemasukan sebagai biaya operasional.

Bangunan LAPAS berpengaruh pada psikologis anak, apalagi anak yang terpaksa berada di LAPAS dewasa di mana kesan pemidanaannya lebih terasa. Sebab konsep utama LAPAS umumnya berorientasi pada kebutuhan keamanan, mencegah agar anak di dalam LAPAS tidak melarikan diri. Jeruji, layout ruangan yang kurang tepat, kawat berduri, tembok tinggi, warna dinding yang suram berpengaruh besar pada daya minat anak untuk mengikuti pembinaan khususnya pendidikan. Untuk itu Indonesia dapat mencontoh dengan negara Thailand dalam hal ini.

Permasalahan sumber daya manusia (SDM) di Indonesia dapat mencontoh dari negara Malaysia dimana untuk pendidikan formal bagi anak yang berkonflik dengan hukum dilakukan oleh guru-guru yang berkualitas yang ditunjuk oleh kementerian pendidikan dan mengikuti kurikulum yang sama seperti pada sekolah negeri. Anak-

\footnotetext{
${ }^{20}$ Nurini Aprilianda, Op. Cit, hal.96
} 
anak tersebut juga mengikuti ujian akhir yang sama dengan anak-anak di masyarakat luar dengan status yang sama, sehingga untuk dokumen pendidikan berupa ijasah tidak ada yang menunjukkan bahwa mereka bersekolah di Lembaga Pembinaan Khusus Anak (LPKA). Untuk itu Kementerian pendidikan dapat mengeluarkan kebijakan agar institusi pendidikan dapat bekerja sama dengan Lembaga Pembinaan Khusus Anak (LPKA) dalam memberikan pendidikan sebab pendidikan merupakan hak dasar setiap warga dan negara bertanggung jawab terhadap warga negaranya tanpa kecuali sesuai amanat Undang-Undang Dasar Negara Republik Indonesia Tahun 1945. Untuk program pendidikan nonformal maupun informal perlunya dikembangkan bentuk kerjasama antar kementerian seperti kementerian Koperasi dan UKM untuk memberikan pelatihan dan pendidikan keterampilan, kementerian industri dan perdagangan untuk memberikan pelatihan, pendidikan ketrampilan, dan juga perlu ditingkatkan kerjasama dengan Lembaga Swadaya Masyarakat (LSM) pemerhati anak, Komisi Perlindungan Anak Indonesia yang bertanggung jawab sebagai pengawasan lapas anak, dan sebagainya. Sistem pembinaan bagi anak yang berkonflik dengan hukum selama dalam Lembaga Pembinaan Khusus Anak (LPKA) dapat dilakukan dengan pemberian reward and punishment (hadiah dan hukuman). Seperti yang dilakukan di negara Malaysia yaitu dengan adanya sistem ranking. Yang mana apabila anak berperilaku baik maka mereka akan mendapatkan hadiah berupa cuti bersama keluarga diluar lembaga, namun apabila mereka berperilaku tidak baik maka akan mendapatkan hukuman seperti baris berbaris, ditempatkan di ruang isolasi dan sebagainya. pemberian reward and punishment dapat pula digunakan untuk menumbuhkan minat anak yang berkonflik dengan hukum dalam mengikuti program pendidikan, keterampilan dan keahlian yang diberikan oleh lembaga pemasyarakatan.

Pemenuhan hak pendidikan terhadap anak di Lembaga Pembinaan Khusus Anak (LPKA) memberikan kebebasan penuh kepada anak untuk berkembang, dengan diarahkan melalui pengajaran yang sesuai dengan kurikulum yang berlaku sebagai acuan dasar di dalam pendidikan. Maka dengan memberikan pendidikan yang sesuai dengan kebutuhan bagi anak sebagai narapidana hal ini akan mempengaruhi tingkat kematangan anak dalam hal cara berpikir sehingga diharapkan anak setelah menjalani masa hukumannya dapat diterima kembali pada lingkungan keluarga, teman dan masyarakat sekitarnya. sehingga dapat tercapai tujuan pidana bagi anak bukan pada penghukuman, tetapi perbaikan kondisi, pemeliharaan dan perlindungan anak serta pencegahan pengulangan tindakannya dengan pendekatan keadilan restoratif.

\section{B. Mewujudkan Pemenuhan Hak Anak Atas Pendidikan Selama Di Dalam Lembaga Pembinaan Khusus Anak (LPKA)}

Masyarakat merupakan komponen yang sangat penting dalam membantu proses pembinaan narapidana dalam rangka terwujudnya tujuan pemasyarakatan. Peran masyarakat sangat diperlukan dalam proses pengembalian narapidana ke masyarakat. Di dalam Pasal 9 ayat (1) Undang-Undang Nomor 12 Tahun 1995 tentang Pemasyarakatan, yang menegaskan dalam rangka penyelenggaraan pembinaan dan pembimbingan Warga Binaan Pemasyarakatan, menteri dapat mengadakan kerjasama dengan instansi pemerintah terkait, badan-badan kemasyarakatan lainnya atau perorangan 
yang kegiatannya seiring dengan penyelenggaraan sistem pemasyarakatan.

Partisipasi masyarakat juga diatur dalam Pasal 5 Peraturan Pemerintah Nomor 31 Tahun 1999 tentang Pembinaan dan Pembimbingan Warga Binaan Pemasyarakatan, yang menyebutkan bahwa dalam rangka penyelenggaraan pembinaan dan pembimbingan warga binaan pemasyarakatan, menteri dapat mengadakan kerjasama dengan instansi pemerintah terkait, badan-badan kemasyarakatan lainnya, atau perorangan yang kegiatannya sesuai dengan penyelenggaraan sistem pemasyarakatan.

Terkait dengan Anak yang berkonflik dengan hukum pada Pasal 93 UndangUndang Nomor 11 Tahun 2012 tentang Sistem Peradilan Pidana Anak menjelaskan bahwa masyarakat dapat berperan serta dalam perlindungan anak mulai dari pencegahan sampai dengan reintegrasi sosial anak dengan cara:

1) Menyampaikan laporan terjadinya pelanggaran hak anak kepada pihak yang berwenang;

2) Mengajukan usulan mengenai perumusan dan kebijakan yang berkaitan dengan anak;

3) Melakukan penelitian dan pendidikan mengenai anak;

4) Berpartisipasi dalam penyelesaian perkara anak melalui diversi dan pendekatan keadilan restoratif;

5) Berkontribusi dalam rehabilitasi dan reintergrasi sosial anak, anak korban dan/atau anak saksi melalui organisasi kemasyarakatan;

6) Melakukan pemantauan terhadap kinerja aparat penegak hukum dalam penanganan perkara anak; atau

7) Melakukan sosialisasi mengenai hak anak serta peraturan perundangundangan yang berkaitan dengan anak.
Namun stigma negatif terhadap anak yang pernah menjalani hukuman di Lembaga Pemasyarakatan masih sering diberikan oleh masyarakat. Sehingga anak yang berkonflik dengan hukum tersebut kemungkinan besar dapat mengulangi perbuatannya tersebut. sehingga konsep reintegrasi sosial dengan masyarakat perlu dilakukan terhadap anak baik pada saat di dalam Lembaga Pemasyarakatan ataupun pada masa menjelang bebas.

Sayangnya di Indonesia, lembagalembaga non pemerintahan khususnya di daerah seperti Lembaga Swadaya Masyarakat, Yayasan Sosial, Komisi Perlindungan Anak Daerah, Pusat Pelayanan Terpadu Pemberdayaan Perempuan dan Anak Kota, dan lainnya, belum sama sekali menjangkau anak yang berkonflik dengan hukum yang berada di Lembaga Pembinaan Khusus Anak, sebagaimana kita ketahui asas perlindungan anak adalah nondiskriminasi. Sudah sepatutnya mereka sama seperti anak diluar Lembaga Pemasyarakatan mendapatkan hak-hak sesuai yang diamanatkan pada undang-undang. Pada saat pemerintah tidak mampu memenuhi hak-hak tersebut khususnya hak atas pendidikan, sudah sepantasnya anak yang berkonflik dengan hukum tidak dipenjara. Karena seperti yang diamanatkan pada Undang-Undang Nomor 11 Tahun 2012 tentang Sistem Peradilan Pidana Anak bahwa hukuman pidana penjara adalah merupakan hukuman terakhir yang diberikan kepada anak.

Dalam hal ini peneliti melihat perlu ada pula pemanfaatan program bantuan hukum melalui kerjasama dengan Lembaga Bantuan Hukum (LBH) atau Lembaga Konsultasi Bantuan Hukum (LKBH) yang berada di bawah naungan suatu universitas, dan pemanfaatan program Corporate Social Responsibility (CSR) dari beberapa perusahaan untuk mendukung pendidikan di Lembaga Pembinaan Khusus Anak 
(LPKA). Dalam menjalin kerjasama dengan perusahaan-perusahaan dengan pemanfaatan program Corporate Social Responsibility (CSR) tentu dapat dilihat dari potensi masing-masing daerah sesuai dengan karakteristiknya sebagai upaya untuk mewujudkan pemenuhan hak atas pendidikan bagi anak yang berkonflik dengan hukum di Lembaga Pembinaan Khusus Anak (LPKA).

Sebagaimana sudah dimandatkan dalam pembukaan Undang-Undang Dasar Negara Republik Indonesia Tahun 1945, salah satu tujuan negara adalah mencerdaskan kehidupan bangsa. Ini berarti negara, dalam hal ini penyelenggara negara/pemerintah, harus mengambil peran besar dalam penyelenggaraan pendidikan nasional, dan pada dasarnya pendidikan merupakan suatu penaggulangan dalam menciptakan sumber daya manusia yang maksimal. Hal ini dikarenakan pendidikan adalah aspek dasar dalam pencapaian sektor pembangunan baik pada sektor ekonomi, sektor politik, sektor hukum, sektor sosial budaya, dan perangkat sektor lainnya yang berkaitan dengan pembangunan kerakyataan dalam pelaksanaan pemerintahan kenegaraan.

Hak atas pendidikan merupakan bagian dari hak asasi manusia sesuai dengan ketentuan Pasal 28C ayat (1) Undang-Undang Dasar Negara Republik Indonesia Tahun 1945 yang menyatakan bahwa setiap orang berhak mengembangkan diri melalui pemenuhan kebutuhan dasarnya, berhak memperoleh manfaat dari ilmu pengetahuan dan teknologi, seni dan budaya, demi meningkatkan kualitas hidupnya dan demi kesejahteraan umat manusia. Pemenuhan hak tersebut dimaksudkan bahwa seluruh warga negara Indonesia dapat mengemban pendidikan yang layak untuk meningkatkan taraf kehidupannya.
Pemenuhan hak warga negara atas pendidikan juga tertuang dalam ketentuan Pasal 31 ayat (2) Undang-Undang Dasar Negara Republik Indonesia Tahun 1945 yang merumuskan bahwa setiap warga negara wajib mengikuti pendidikan dasar, sedangkan pemerintah wajib membiayainya. Kemudian Pasal 31 ayat (3) dan ayat (4) menegaskan bahwa pemerintah memiliki kewajiban untuk mengusahakan penyelenggaraan pengajaran nasional dalam rangka mencerdaskan kehidupan bangsa dengan memprioritaskan anggaran sekurang-kurangnya 20 (dua puluh) persen dari Anggaran Pendapatan Dan Belanja Negara (APBN) dan Anggaran Pendaapatan dan Belanja Daerah (APBD). Sesuai dengan ketentuan pasal tersebut maka dapat disimpulkan bahwa negara bertanggung jawab atas pemenuhan hak warga negara atas pendidikan. Yang dimaksud negara dalam hal ini bukan saja pemerintah pusat, melainkan pemerintah daerah juga memiliki peran besar atas pendidikan bagi setiap warga negara dengan tujuan untuk mencerdaskan kehidupan bangsa yang merupakan salah satu tujuan dari Negara Kesatuan Republik Indonesia. Pemerintah disini juga termasuk dengan keterlibatan semua lembaga yang ada di Indonesia yang sekiranya dapat dilakukan guna pemenuhan hak anak atas pendidikan khususnya anak yang berkonflik dengan hukum pada Lembaga Pembinaan Khusus Anak (LPKA), seperti yang dapat kita lihat di negara Filipina dimana sistem peradilan pidana anak dilaksanakan oleh Dewan Keadilan dan Kesejahteraan bagi anak (Juvenile Justice and Welfare Council yang disingkat JJWC). Adapun anggota dari JJWC adalah Departemen Kesejahteraan Sosial dan Pembangunan, Departemen Hukum, Departemen Pendidikan, Departemen Dalam Negeri dan Pemerintahan Lokal, Komisi Hak Asasi 
Manusia, Komisi Pemuda Nasional, dan Lembaga Non Pemerintahan lainnya.

Didalam Undang-Undang Nomor 11 Tahun 2012 tentang Sistem Peradilan Pidana Anak hanya mencantumkan bahwa anak yang dijatuhi pidana penjara yang ditempatkan di Lembaga Pembinaan Khusus Anak (LPKA) berhak memperoleh pembinaan, pembimbingan, pengawasan, pendampingan, pendidikan dan pelatihan, serta hak-hak lain sesuai dengan ketentuan peraturan perundang-undangan. Namun undang-undang ini tidak secara eksplisit menentukan hak anak yang ada didalam Lembaga Pembinaan Khusus Anak (LPKA) untuk tetap dapat melaksanakan pendidikannya. Sehingga dalam hal ini perlu dibuat sebuah regulasi yang melindungi pemenuhan hak atas pendidikan terhadap anak yang berkonflik dengan hukum selama menjalani masa hukumannya di Lembaga Pembinaan Khusus Anak (LPKA).

Dalam regulasi tersebut dapat memuat pelaksanaan program di Lembaga Pembinaan Khusus Anak (LPKA) melalui kerjasama dengan instansi-instansi terkait seperti Kementerian Pendidikan Dasar dan Menengah, Kementerian Pendidikan dapat mengeluarkan kebijakan agar institusi pendidikan tidak diperbolehkan menolak anak untuk mendapatkan pendidikan di institusinya sebab pendidikan merupakan hak dasar setiap warga dan negara bertanggung jawab terhadap warga negaranya kecuali sesuai dengan amanat Undang-Undang Dasar Negara Republik Indonesia Tahun 1945. Kerjasama lainnya dengan Kementerian Koperasi dan UKM untuk memberikan pelatihan dan pendidikan ketrampilan, Kementerian Industri dan Perdagangan juga dapat memberikan pelatihan, pendidikan ketrampilan, Kementerian Sosial pada saat asimilasi, Kementerian Pemberdayaan Perempuan dan Anak, Kementerian Dalam
Negeri, Kementerian Kesehatan, Kementerian Agama, Kementerian Koordinator Pembangunan Manusia dan kebudayaan, dan masih banyak lagi instansi-instansi terkait yang dapat memberikan sumbang asih terhadap pemenuhan hak atas pendidikan terhadap anak yang berkonflik dengan hukum di Lembaga Pembinaan Khusus Anak (LKPA). Hal ini bisa terwujud apabila setiap instansi terkait memahami bahwa asas perlindungan terhadap anak adalah salah satunya untuk mengutamakan kepentingan terbaik untuk anak.

\section{PENUTUP}

\section{A. Kesimpulan}

Berdasarkan dari analisis yang termuat di dalam pembahasan, maka dapat disimpulkan bahwa:

1) Mengenai pemahaman bahwa negara menjamin hak setiap anak atas kelangsungan hidup, tumbuh dan berkembang termasuk didalamnya yaitu hak anak untuk menikmati standar kehidupan yang memadai dan hak atas pendidikan. Pasal 60 ayat (1) Undang-Undang Nomor 39 Tahun 1999 tentang Hak Asasi Manusia menyebutkan bahwa setiap anak berhak untuk memperoleh pendidikan dan pengajaran dalam rangka pengembangan pribadinya sesuai dengan minat, bakat dan tingkat kecerdasannya. Di dalam Sistem Peradilan Pidana Anak dijelaskan bahwa pembinaan anak di dalam lembaga pemasyarakatan mengedepankan pendidikan yang layak. Dan lembaga pemasyarakatan khusus anak atau dikenal dengan Lembaga Pembinaan Khusus Anak (LPKA) wajib menyelenggarakan pendidikan, pelatihan keterampilan, pembinaan, dan pemenuhan hak lain 
sesuai dengan ketentuan peraturan perundang-undangan.

2) Adapun konsep pembinaan anak di Lembaga Pembinaan Khusus Anak (LPKA) dapat mengadopsi pembinaan yang dilakukan di beberapa negara seperti Malaysia, Thailand dan Filipina. Misalnya seperti di Thailand bangunan lembaga pembinaan anak tidak seperti bangunan penjara seperti biasanya yang mana dapat membuat kondisi rentan secara psikologis terhadap anak. Penjara di lembaga pemasyarakatan berpengaruh besar pada daya minat anak untuk mengikuti pembinaan khususnya pendidikan. Dalam hal sarana prasarana yang menyangkut sumber daya manusia (SDM) maka dapat mengadopsi negara Malaysia yang dimana lembaga pembinaan anak bekerjasama dengan Departemen Pendidikan dalam memberikan pendidikan kepada anak didalam lembaga pemasyarakatan.

3) Untuk pelaksanaan di Indonesia, peran masyarakat dan negara sangat dibutuhkan untuk dapat terlaksananya program di Lembaga Pembinaan Khusus Anak (LPKA), hal tersebut dapat melalui kerjasama dengan instansi-instansi terkait seperti Kementerian Pendidikan Dasar dan Menengah, Kementerian Pendidikan Tinggi, Lembaga Swadaya Masyarakat, Yayasan Sosial, dan lembaga non pemerintah lainnya tanpa kecuali sesuai amanat Undang-Undang Dasar Negara Republik Indonesia Tahun 1945. Selain itu juga kementerian pendidikan dapat membuat standar kurikulum bagi anak yang di Lembaga Pembinaan Khusus Anak.
Pemanfaatan program bantuan hukum melalui kerjasama dengan Lembaga Bantuan Hukum (LBH) atau Lembaga Konsultasi Bantuan Hukum (LKBH) yang berada di bawah naungan suatu universitas, dan pemanfaatan program Corporate Social Responsibility (CSR) dari beberapa perusahaan untuk mendukung pendidikan di Lembaga Pembinaan Khusus Anak (LPKA). Dalam menjalin kerjasama dengan perusahaan - perusahaan dengan pemanfaatan program Corporate Social Responsibility (CSR) tentu dapat dilihat dari potensi masing-masing daerah sesuai dengan karakteristiknya.

\section{B. Saran}

Adapun saran yang dapat disampaikan adalah:

1) Agar dapat terwujud konsep pembinaan anak di dalam Lembaga Pembinaan Khusus Anak (LPKA) yang sesuai dengan pemenuhan hakhak anak perlu perubahan pola pikir atau mindset tujuan pemidanaan anak, pergeseran pemikiran dari penghukuman menjadi pembinaan bagi anak, tidak terlepas dari koordinasi antara lembaga, baik Kementerian Hukum dan Hak Asasi Manusia, Kementerian Sosial, Kementerian Pendidikan, Kementerian Pemberdayaan Perempuan dan Anak, Komisi Perlindungan Anak Indonesia, Lembaga Swadaya Masyarakat, Yayasan dan lembaga-lembaga lainnya yang terlibat dalam pelaksanaan pembinaan anak sesuai dengan Undang-Undang Nomor 11 Tahun 2012 tentang Sistem Peradilan Pidana Anak.

2) Dalam mewujudkan pemenuhan hak anak atas pendidikan di Lembaga Pembinaan Khusus Anak (LPKA) yang terkendala dengan sumber daya manusia, sarana prasarana dan biaya 
operasional, tidak terlepas dari keterlibatan masyarakat, misalnya melalui program Corporate Sosial Responsibility (CSR), program orang tua asuh, beasiswa pendidikan dari swasta dan lain sebagainya. Selain itu pula perlu dibuat sebuah regulasi yang jelas terkait pemenuhan hak-hak anak atas pendidikan, mekanisme pembelajaran, peranan masyarakat dan negara, sampai pada sanksi baik pidana maupun denda kepada mereka yang melanggar pemenuhan hak anak selama berada di Lembaga Pembinaan Khusus Anak (LPKA).

\section{DAFTAR PUSTAKA}

\section{Buku :}

A.Gunawan Setiardja, 1993, Hak-Hak Asasi Manusia Berdasarkan Ideologi Pancasila, Kanisius, Yogyakarta;

Abintoro Prakoso, 2010, Diskresi Pada Tahap Penyidikan Dalam Rangka Mewujudkan Perlindungan Hukum Bagi Anak Nakal, Disertasi pada Program Pascasarjana Fakultas Hukum Universitas Brawijaya, Malang;

, 2016, Pembaharuan Sistem Peradilan Pidana Anak Edisi Revisi, Aswaja Pressindo, Yogyakarta;

Anthony M.Platt, 1977, The Child Savers: The Invention of Delinquency, The University of Chicago Press, Chicago;

Apong Herlina, 2004, Perlindungan Terhadap Anak yang Berkonflik dengan Hukum Manual Pelatihan untuk POLISI, Polri dan UNICEF, Jakarta;

Arif Gosita, 1989, Masalah Perlindungan Anak, Akademi Pressindo, Jakarta;

Bambang Poernomo, 1982, Pandangan Terhadap Asas-Asas Umum Hukum Acara Pidana, Liberty, Yogyakarta;

Bunadi Hidayat, 2010, Pemidanaan Anak di Bawah Umur, Alumni, Bandung;

C.Ray Jeffery, 1977, Crime Prevention Through Environmental Design, Sage Publication, Bevery Hills London;

Departemen Pendidikan dan Kebudayaan, 1991, Kamus Besar Bahasa Indonesia, Balai Pustaka, Jakarta;

Djoko Prakoso, 1988, Surat Dakwaan, Tuntutan Pidana dan Eksaminasi Perkara di Dalam Proses Pidana, Liberty, Yogyakarta; 
Eddy, O.S Hiariej, 2016, Prinsip-Prinsip Hukum Pidana, Cahaya Atma Pustaka, Yogyakarta;

Gerber, Patrick D.Mc Anany, 1970, Philosophy of Punishment, John Wiley \& Sons, New York;

H.Salim, Erlies Septiana Nurbani, 2016, Penerapan Teori Hukum Pada Penelitian Disertasi dan Tesis Buku Ketiga, RajaGrafindo Persada, Jakarta;

Herbert L.Packer, 1988, The limit of the criminal sanction, Standford University Press, California;

Hilman Hadikusuma, 1993, Hukum Adat Dalam Yurisprudensi, Citra Aditya Bakti, Bandung;

Irma Setyowati Sumitro, 1990, Aspek Hukum Perlindungan Anak, Bumi Aksara, Jakarta;

Jan Rammelink, 2003, Hukum Pidana Komentar atas pasal-pasal terpenting dari KUHP Belanda dan padanannya dalam KUHP Indonesia, Gramedia Pustaka Utama, Jakarta;

Jackson Toby, 1970, The Sociology of punishment and correction, Wiley \& Sons, New York;

Kartini Kartono, 2010, Patologi Sosial 2 : Kenakalan Remaja, RajaGrafindo Persada, Jakarta;

1992, Patoloigi sosial Kenakalan Remaja, Rajawali Press, Jakarta;
Komisi Nasional Hak Asasi Manusia, 1997, Hak Asasi Manusia, Gramedia Pustaka Utama, Jakarta;

La Sina, 2016, Hukum Dan Hak Asasi Manusia, Kreasi Total Media, Yogyakarta;

Lamintang, 1988, Hukum Penitensier Indonesia, Armico, Bandung;

Maidin Gultom, 2014, Perlindungan Hukum Terhadap Anak dalam Sistem Peradilan Pidana Anak di Indonesia, Refika Aditama, Bandung;

Marlina, 2009, Peradilan Pidana Anak di Indonesia, Pengembangan Konsep Diversi dan Restorative Justice, Refika Aditama, Bandung;

Moeljatno, 2000, Asas-Asas Hukum Pidana, Rineka Cipta, Jakarta;

Muhammad Joni, Zulchaina Z.Tanamas, 1999, Aspek Hukum Perlindungan Anak Dalam Perspektif Konvensi Hak Anak, Citra Aditya Bakti, Bandung;

Muladi, 1995, Kapita Selekta Sistem Peradilan Pidana, Badan Penerbit Universitas Diponegoro, Semarang; , 2003, Lembaga Pengawasan: Sistem Peradilan Terpadu, MAPPI FHUI, Jakarta;

Nasir Djamil, 2013, Anak Bukan Untuk Di hukum, Sinar Grafika, Jakarta;

Robert C.Trajanowicz, Marry Morash, 1992, juvenile Delinquency: Concepts and Control, Prentice Hall, New Jersey; 
Roeslan Saleh, 1983, Perbuatan Pidana dan Pertanggungjawaban Pidana Dua Pengertian Dasar Dalam Hukum Pidana, Aksara Baru, Jakarta;

Romli Atmasasmita, 1984, Problem Kenakalan Anak dan Remaja, Armico, Bandung;

1996, Sistem Peradilan

Pidana, Perspektif Eksistensialisme dan Abosilisionisme, Bina Cipta, Bandung;

Rotiq Ahmad, 1997, Hukum Islam di Indonesia, RajaGrafindo Persada, Jakarta;

Rika Saraswati, 2015, Hukum Perlindungan Anak di Indonesia, Citra Aditya Bakti, Bandung;

Setya Wahyudi, 2011, Implementasi Ide Diversi Dalam Pembaruan Sistem Peradilan Pidana Anak di Indonesia, Genta Publishing, Yogyakarta;

Soedjono Dirdjosisworo, 1984, Ruang Lingkup Kriminologi, Remadja Karya, Bandung;

1983, Penanggulangan Kejahatan, Alumni, Bandung;

1982 ,

Pemeriksaan Pendahuluan Menurut KUHAP, Alumni, Bandung;

Sudarsono, 1991, Kenakalan Remaja, Rineka Cipta, Bandung;

Umi Chulsum, 2006, Kamus Besar Bahasa Indonesia, Kashiko, Surabaya;
Wirjono Prodjodikoro, 1981, Hukum Acara Pidana di Indonesia, Sumur, Bandung;

1981, Hukum Perkawinan di Indonesia, Sumur, Bandung;

Yahya Harahap, 1993, Pembahasan Permasalahan dan Penerapan KUHAP, Pustaka Kartini, Jakarta;

Zainal Abidin Farid, 2007, Hukum Pidana I, Sinar Grafika, Jakarta.

\section{B. Peraturan Perundang-undangan}

Deklarasi Universal Hak Asasi Manusia (DUHAM), Resolusi Nomor 217A (III) tanggal 10 Desember 1948

Peraturan Minimum Standar Perserikatan Bangsa-Bangsa Mengenai Administrasi Peradilan bagi Anak (The Beijing Rules), Resolusi Nomor 40/33 Tahun 1985

Pedoman Perserikatan Bangsa-Bangsa Dalam Rangka Pencegahan Tindak Pidana Remaja (Riyadh Guidelines), Resolusi Nomor 45/112 Tahun 1990

Konvensi Hak-Hak Anak, Resolusi Nomor 109 Tahun 1990

Republik Indonesia, Undang-Undang Dasar Negara Republik Indonesia Tahun 1945

Republik Indonesia, Undang-undang nomor 39 tahun 1999 tentang Hak Asasi Manusia

Republik Indonesia, Undang-undang nomor 11 tahun 2012 tentang Sistem Peradilan Pidana Anak 
Republik Indonesia, Undang-undang nomor 35 tahun 2014 tentang Perubahan Atas Undang-undang nomor 23 tahun 2002 tentang Perlindungan Anak

Republik Indonesia, Undang-Undang Nomor 20 Tahun 2003 tentang Sistem Pendidikan Nasional

Republik Indonesia, Undang-Undang Nomor 12 Tahun 1995 tentang Pemasyarakatan

Republik Indonesia, Peraturan Pemerintah Nomor 31 Tahun 1999 tentang Pembinaan dan Pembimbingan Warga Binaan Pemasyarakatan

Republik Indonesia, Keputusan Presiden Nomor 36 Tahun 1990 tentang Pengesahan Konvensi Hak-Hak Anak (Convention on the Rights of the Child)

\section{Tesis}

Mukhamad Tri Setyobudi, 2012, Pembinaan Anak Pidana Di Lembaga Pemasyarakatan Anak Tanggerang, Tesis, Program Magister Ilmu Hukum Universitas Indonesia, Jakarta;

Novie, Amalia Nugraheni, 2009, Sistem Pemidanaan Edukatif Terhadap Anak Sebagai Pelaku Tindak Pidana, Tesis, Fakultas Hukum Universitas Semarang.

\section{Jurnal}

Alden Juniedy Simanjuntak, 2013, Perlindungan Hukum Terhadap Anak Yang Menjalani Pidana Penjara Di Lembaga Pemasyarakatan Anak Kelas IIB Pontianak, Jurnal Nestor Magister Hukum, Vol.2, No.2 Tahun 2013;

Asri Rima Jiwantari, 2017, Manajemen Pembinaan Anak Didik Pemasyarakatan Studi Kasus LPKA Kelas II Jakarta, Jurnal Ilmiah untuk peningkatan mutu manajemen pendidikan, Vol.4, No.1 tahun 2017;

Badan Koordinasi Penanggulangan Kenakalan Remaja dan Penyalahgunaan Narkotika Sumatera Utara, 1979, Pola Penanggulangan Kenakalan Remaja, Makalah, Medan;

Marzuki Darusman, 1999, Hak-Hak Asasi Manusia dan Supremasi Hukum, Dalam Majalah Hukum Projustitia Tahun XVII Nomor 4 bulan Oktober 1999, Fakultas Universitas Katolik Parahyangan, Bandung;

Purnianti, 1993, Garis Besar Analisa Situasi Sistem Peradilan Pidana Anak di Indonesia, Seminar sehari peradilan anak mengembangkan Diversi dan Restorative Justice, Hotel Interontinental M.Plaza, Jakarta; 